Dept. of Anat., Kyoto Prefectural Med. College (Director: Prof. Dr. H. NODA).

\title{
Histological Studies of the Neurosecretory Nuclei. \\ IV. On the Amitosis Like Findings in the Hypothalamic Neurosecretory Nuclei of Dog.
}

\author{
(Contributions to the Comparative Histology of the Hypothalamo- \\ hypophysial System. 31st report.) \\ 神経分泌核の組織学的研 究. \\ IV. 視床下部神経分泌核（犬）に招ける細胞分裂様所見について。
}

（視床下部下垂体系の比較組織学的研究. 第 31 報.)

\section{Yutaka SANO, Miyozō TAMIYA and Naoji ISHIZAKI}

佐野豊, 田宮三代三，石崎直司。

(Received February 12, 1957.)

In the peripheral autonomic nervous system, multinuclear nerve cells are frequently found even in human adults, especially in gangliated cord, prostatic plexus, periadrenal ganglions or plexus in the seminal vesicle. Sympathetic ganglion cells of rabbits are commonly found to be multinuclear. As the mitotic function of the nerve cell is generally believed to be completely lost already in the newly born, two fundamentally different hypotheses have been given as to the appearance of multinuclear nerve cells. In one it is attributed to amitotic division of the nucleus, in the other to the fusion of cells. In the former case, two different opinions are included in it. One opinion is that these are phenomena resulting from the survival of immature, undifferentiated cells and the other opinion is that the ability of division is still well preserved in cells of the autonomic nervous system even in adults. However, descriptions on multinuclear cells in the central nervous system are limited to just a small portion of the brain, namely the nerve cells of the hypothalamus. E. SCHARRER and GAUPP (1933) observed multinuclear nerve cells in the neurosecretory supraoptic nucleus of a 17 year old girl who died of carbonic acid gas poisoning. CELESTINO DA COSTA (1923), HECHST (1930), ROUSSY and MOSINGER (1937), CHRIST (1951--1952) and HAGEN (1952) have each observed these cells to exist in the nucleus infundibularis. There are, as mentioned above, various opinions about the appearance of multinuclear nerve cells. However, these cells in the hypothalamus are generally believed to be the results of amitosis. In this case, CHRIST and ROUSSY 
and MOSINGER believe that the replacement of the dead nerve cells in the hypothalamus is carried out by the amitotic division of the nerve cells. On the other hand, CELESTINO DA COSTA believes that the supplement of nerve cells is carried out by undifferentiated ependymal cells and HAGEN by neurogliar element. E. SCHARRER and BARGMANN, both of whom have made extensive studies on neurosecretion, presume the manner of neurosecretion to be merocrine and consequently give no consideration to the loss of neurosecretory cells. However, HAGEN (1952) has given the opinion that the death of neurosecretory cells may take place due to 'physiological degeneration', in other words, due to holocrine secretion, and we have also made a report on its possibility (15th report). Since the neurosecretory cell is capable of persecuting a function similar to that of the common glandular cell, consideration should be given to the possibility of the death of cells and its supplement. In this case, the supplement must be made by the neighboring cells. Findings favoring this point of view may be derived from a report (TAMURA etc. 1955) which states that in Mugil cephalus, a bony fish, amitotic cell division figures arefrequently seen in the neurosecretory preoptic nucleus. But, findings showing cell division in the hypothalamic neurosecretory nuclei of dogs or cats have not yet been reported. We have previously reported on the possibility of holocrine secretion, but as to the problems concerning the supplement of cells, no conclusive evidence has been given.

Based on the evidence obtained in the study, some consideration will be made on the possibility of cell division existing also in the neurosecretory supraoptic and paraventricular nuclei.

Materials and methods will be given in each corresponding case.

\section{Observation.}

Fig. 1. Pars ventromedialis nuclei supraoptici of an adult male dog, weighing $9 \mathrm{~kg}$. Ravonal (Thiopental sodium) narcosis, $10 \%$ neutral formalin fixation, $20 \mu$ freezing section. Double staining by GROS-SCHULTZE's silver impregnation method and GOMORI's aldehyde-fuchsin method.

Many of the neurosecretory cells forming the supraoptic nucleus are observed to be present in pairs, and in some, the isolation of an individual cell seems to be difficult to recognize and the cytoplasm of both cells are seen confluent with each other. But no difference in the size of the cells and their nuclei are observed between the cells forming pairs and those of the solitary cells. And also no difference in intranuclear structure is observed between these two types of cells. Cells forming a pair are observed in all sections from pars ventromedialis, so these findings are not due to the direction of the knife in sectioning with the microtome.

Fig. 2. Supraoptic nucleus of an adult female dog weighing $8 \mathrm{~kg}$. 
Ravonal narcosis, Levi fixation, $5 \mu$ paraffin section. Stained with HEIDENHAIN's iron-hematoxylin.

The cytoplasm of the cells in pairs are undoubtedly continued and no space is found between these two cells. But narrowing in the connecting part between the two cells, roughness of cytoplasm, and linear figures parallel to the axis connecting both nuclei are observed. Neither change in nuclear structure such as abnormality in chromatin nor appearance of chromosomes is observed. In this case, no other instance like this was found.

Fig. $3 a, b$ and $c$. An adult male dog, weighing $7 \mathrm{~kg}$. Ravonal narcosis, BOUIN's fluid fixation, paraffine embedding, $8 \mu$ sectioning. Stained by GOMORI's chromealum-hematoxylin phloxine method.

The findings here were obtained from a dog with remarkably thinned posterior lobe due to the compression caused by a large colloidal cyste which may have originated from the distal ending of the intermediate lobe. But the quantity of neurosecretory material and its state of distribution in the posterior lobe and neurosecretory pathway were found to be similar to those of the normal one.

Fig. 3 a. A neurosecretory nerve cell suggesting amitotic cell division in the pars ventromedialis nuclei supraoptici. A pair of cells with two resting nuclei is seen here connected by a relatively long process like portion. On the opposite side of one of them an unipolar axon is observed. Gomoriphil neurosecretory material is found to be present in the cell bodies and in the connecting portion. In the connecting portion, neurosecretory material is seen along the border forming 2 rows. The nucleolus is stained well with phloxine and no abnormality in chromatin in the nucleus is observed.

Fig. $3 \mathrm{~b}$. Two continuous neurosecretory cells in the nucleus paraventricularis accessorius. The cytoplasm of two cells fuse widely with each other and no narrow connecting portion is seen between them. Neurosecretory material is abundant in both cells. Here the structure of one nucleus is unclear and in the other an incision is observed.

Fig. 3 c. A nerve cell suggesting amitotic cell division in the supraoptic nucleus. Due to the continuation of both cells the figure here is something horse-shoe shaped. And an endocellular capillary is seen in the cytoplasm connecting both cells.

Though characteristic findings such as those seen in Fig. $3 \mathrm{a}, \mathrm{b}$ and $\mathrm{c}$ were very frequently observed in this dog, no definite conclusion can be given as to the relation of these findings and the cyst developing in the pituitary gland.

Fig. 4. An adult female dog, weighing $12 \mathrm{~kg}$. A neurosecretory cell in the paraventricular nucleus. Ravonal narcosis, LEVI's fluid fixation, $5 \mu$ 
paraffine sectioning. Stained by HEIDENHAIN's iron-hematoxylin.

In this nerve cell, the nucleolus appearing to be at the verge of division is seen in the nucleus. And here, a septum is seen running through the boundary portion of the dividing nucleolus and extending into the whole nucleus. No indication suggesting amitotic division is seen in the cell body itself and no neurosecretory granule staining to iron-hematoxylin is seen.

\section{Consideration.}

The findings above are all those obtained from nerve cells of neurosecretory supraoptic and paraventricular nuclei. Though no conclusive evidence of amitotic division of the neurosecretory cell could be obtained from these 4 cases of the dogs studied, neither vesiculation nor pycnosis of the cell nucleus could be seen. In view of this fact, these findings should not be considered to be merely the result of a confluence of cells. The findings in Fig. 2, showing linear structure running longitudinal in the cytoplasmic bridge may well suggest amitotic cell division. The findings in Fig. 3, showing an abundant appearance of cells in characteristic figures may be interpreted to express the regeneration and supplement of the neurosecretory tissue. As shown by E. SCHARRER and B. SCHARRER (1954), HAGEN (1952), KASTL (1954) and SANO et al. (1955), neurosecretory cells possess neurofibrils, as well as NISSL's substance and the axon. Consequently, the neurosecretory cells are actually considered histologically to be nerve cells, acquiring also secretory function. However, these cells of high secretory activity should not be considered on the basis similar to the common nerve cells. In contrast to the common nerve cell of the central nervous system, which shrinks in size of the cell body and of the nucleus under dehydration, the nucleus volume of the hypothalamic neurosecretory cell is then found to increase and its activity highly enhanced (MACHER 1952, EICHNER 1952, TAMIYA, IMOTO and TAKAHASHI 1956). This fact is thought to be evidence that neurosecretory cells are essentially different from the common nerve cells. Neurosecretory cells are, as stated above, demonstrated to possess neurofibrils, but these neurofibrils are found to be resistant to silver staining in the cell body, whereas those of the anterior horn motor cells and the giant pyramidal cells in the cerebral cortex etc. are easily stained. Nothing in detail in this respect has been given in the report of E. SCHARRER and B. SCHARRER (1954) concerning the studies on dog's supraoptic nucleus with BODIAN's protargol method, nor in the report of MAZZI (1952) concerning studies of eel's preoptic nucleus with CAJAL's method No. 2.

Attention should be given to the fact that HAGEN and KASTL, both of whom have made extensive study on neurofibril, oppose to the 
opinion of neurosecretion.

Reports on neurofibril changes in each phase of neurosecretory activity will be given later, but we may clearly state here that some percentage of the hypothalamic neurosecretory cells do not show the existence of neurofibrils. These problems have been summarized as physiological degeneration (holocrine secretion) by HAGEN from the neurohistological standpoint in his studies on the changes of nucleus and cytoplasm. Even though some findings may be considered to suggest "physiological degeneration', it is well known since the investigation of BARGMANN (1949) and many other investigators that all neurosecretory cells are not transported to the posterior lobe by mode of holocrine secretion. Merocrine secretion is undoubtedly the chief manner of neurosecretion. But it is affirmed that holocrine discharge too can be occasionally observed in normal condition (NODA, SANO and ISHIZAKI 1955). The findings we have given are considered to indicate the supplement of cells for this manner of secretion, and this supplement is not made by the cells of nucleus infundibularis or gliar elements but by the supraoptic and paraventricular neurosecretory cells itself.

\section{Conclusion.}

Findings suggesting amitotic division of neurosecretory cells of supraoptic and paraventricular nuclei of adult dogs have been described with 6 microphotographs. In one case, most of the nerve cells of pars ventromedialis nuclei supraoptici were observed to be present in pairs. In another case, many multinuclear nerve cells suggesting amitotic division were observed. In still others, findings suggesting the division of a cell nucleus were also obtained.

In view of the reports of HAGEN (1952), NODA, SANO and ISHIZAKI, stating that some of the neurosecretory cells die in the manner of holocrine secretion, these findings are considered to indicate the possibility of the supplement of neurosecretory cells by the amitotic division of the neurosecretory cells.

\section{内 容 自 抄.}

視床下部の神経分泌細胞に打ける分泌様式は一般に漏出型乃至は離出型 と考光られているために，神経分泌細胞の補充ということも殆ど考察され ていない，我々は，視床下部の神経分泌は正常の状態では主として部分分 泌の形式の下に行われているが，一部には全分泌型式の分泌も存し，非生 理的な条件下ではこの形式の分泌が増加すると考光ている. しかし全分泌 による神経分泌細胞の消耗に対する補充の問題に対してはな招明快な見解 を得るにいたっていない，本篇に挌いて報告したのは 4 例の犬の視索上核 
及び脳室旁核に括ける神経分泌細胞の無糸分裂様所見であり，とれは確実 な無糸分裂像とは断定し得ないが，写真に示されたように，多分に無糸分 裂の現象を推定させる特異な所見である。図 1 は視索上核から得たもので あって，神経分泌細胞の多くのものが 2 個ずつ対をなして和り，そのある ものでは両細胞が原形質性の連絡を示している，図 2 も成犬の視索上核か ら得たものであるが，雨細胞の連続するくびれの部分に両核を結ぶ方向の 線状構造が認められる。染色体は現われていない. 図 3 の 3 写真は何れも, 下垂体に生じた大きい囊腫のためと後葉が压平されていた 1 例の犬から得 たものである. 図 3 a は視索上核に認めたもので，休止核を示す 2 個の神 経分泌細胞が細長な部分によって連絡されて括り，一方の細胞の反対極か らは 1 本の軸索が出ている。細胞体にも連絡部にも神経分泌物が含まれて いる. 図 $3 \mathrm{~b}$ は副脳室旁核に見られたもので, 多量の神経分泌物を含む 2 個の細胞が細胞質の広い表面で連続して招り，一方の細胞核は構造が不明 瞭となり，他方の細胞核には切痕部がある。図 $3 \mathrm{c}$ 柱視索上核から得たも ので，2 個の神経分泌細胞が細胞質性に連続して蹄鉄形を呈し，しかも連 続部の中に毛細血管が認められる。図 $3 \mathrm{a}-\mathrm{c}$ の各所見と下垂体囊腫との関 係の有無飞ついては何れとも断定し得ない，図 4 は正常な成犬の脳室旁核 に見出されたもので，核小体があたかも分裂の過程にあるような観を呈し， その境界線から更に細胞核を 2 分する中隔が延びているが，細胞体自身に は分裂所見は存しない。

従来，未梢自律神経系には多核神経細胞が稀ならず認められ，無系分裂 説或は細胞融合説によって説明されているが，中枢自律神経系に括ける多 核細胞に関する報告は殆ど視床下部に限られ，それらは核の無糸分裂の所 産と考えられている，田村，近藤等（1955）飞よって一部の硬骨魚の視束 前核には多数の神経分泌細胞の無糸分裂が認められることが報告されてい るが, 犬や猫の視床下部の神経分泌細胞に拉ける無糸分裂或は無糸分裂様 の所見については従来全く報告されていない，我々は正常神経分泌の一部 飞認められる全分泌, 換言すれば神経細胞の変性死飞対する補充は, Hagen （1952）等が漏斗核について主張しているような，未分化な神経膠性要素 の分化によって行われるものではなく，恐らく神経分泌細胞自身の無系分 裂によってなされるものであろうと考察する。

\section{References.}

Bargmann, W.: Z. Zellforsch. 34 (1949). S. 610. - Christ, J.: Dtsch. Z. Nervenhk. 165 (1951). S. $340 . \quad$ - Acta neuroveg. 3 (1952). S. 267. - Eichner, 
D. : Z. Zellforsch. 37 (1952). S. 406 - Hagen, E.: Acta anat. 16 (1952). S. 367. - Hechst, B. : Arch. psychiatr. 91 (1930). S. 319. - Kastl, E.: Acta neuroveg. 8 (1954). S. 437. - Macher, E.: Verh. anat. Ges. 1952. S. 95. - Mazzi, V.: Rend. Accad. naz. Lincei, Ser. 8, 12 (1952). S. 347. - Noda, H., Y. Sano u. N. Ishizaki : Arch. hist. jap. 9 (1955). S. 205. (Jap. m. dtsch. Zfass.) - Roussy, G. et M. Mosinger: Presse Med. 45 (1937). P. 433. - Sano, Y., Y. Nakagawa, K. Okuno u. N. Otsuka : Arch. hist. jap. 7 (1955). S. 631. (Jap. m. dtsch. Zfass.) - Scharrer, E. u. B. Scharrer : Möllendorffs Handbuch der mikroskopischen Anatomie des Menschen. Bd. 6. Tl. 5. Innersekr. Drüsen. V. Neurosekretion. 1954. - Scharrer, E. u. R. Gaupp: Z. Neur. 148 (1933). S. 766. Tamiya, M., T. Imoto u. S. Takahashi: Arch. hist. jap. 10 (1956). S. 181. (Jap. m. dtsch. Zfass.) - Tamura, J., K. Yashiki, E. Kondo a. H. Oki : Hiroshima J. Med. Sci. 4 (1955). P. 1. 
Explanation of Plate-figures.

Fig. 1. $\times 250$

Fig. 2. $\times 600$

Fig. 3 a. $\times \mathbf{4 0 0}$ 
Y. SANO, M. TAMIYA and N. NISHIZAKI (1)
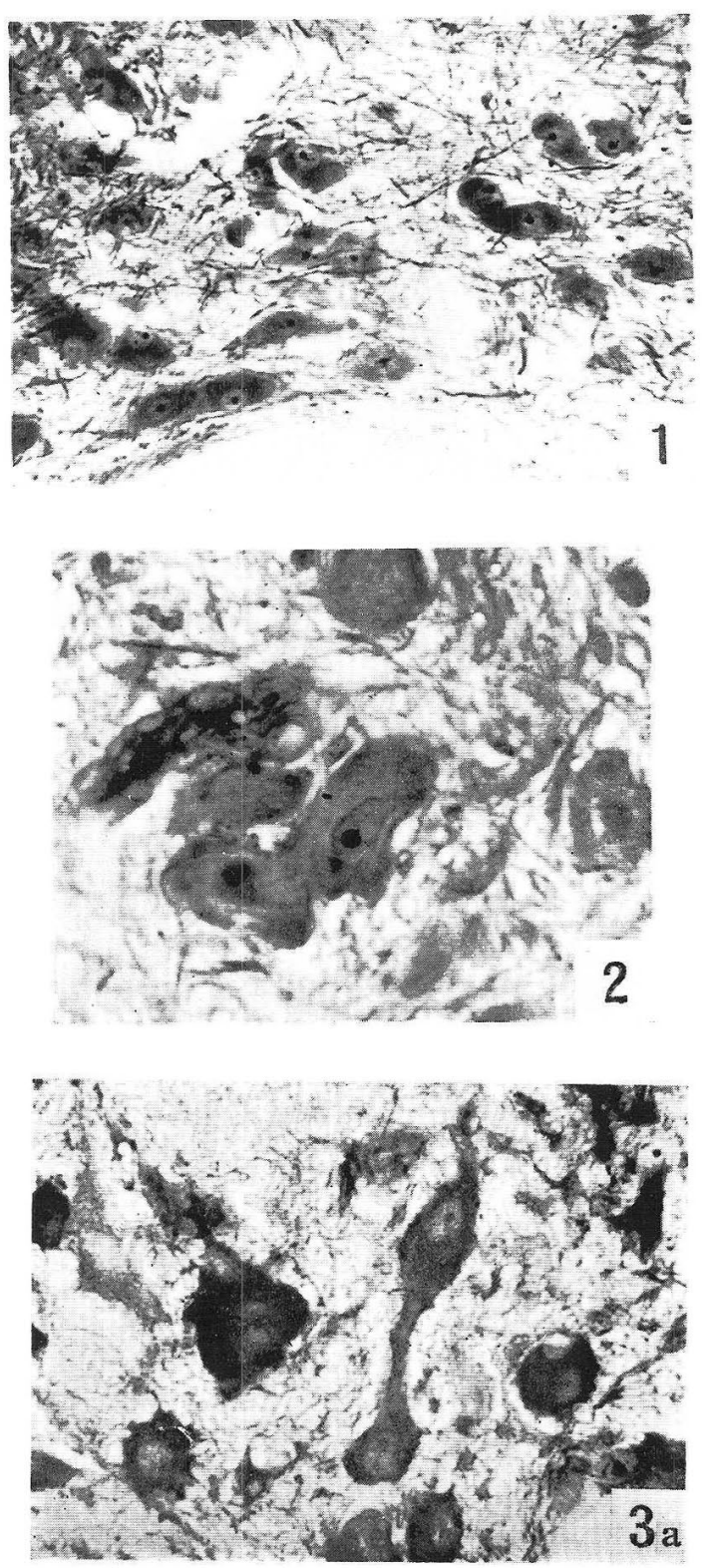
Fig. 3 b. $\times 400$

Fig. 3 c. $\times 400$

Fig. $4 . \quad \times 760$ 
Y. SANO, M. TAMIYA and N. NISHIZAKI ( 2 )
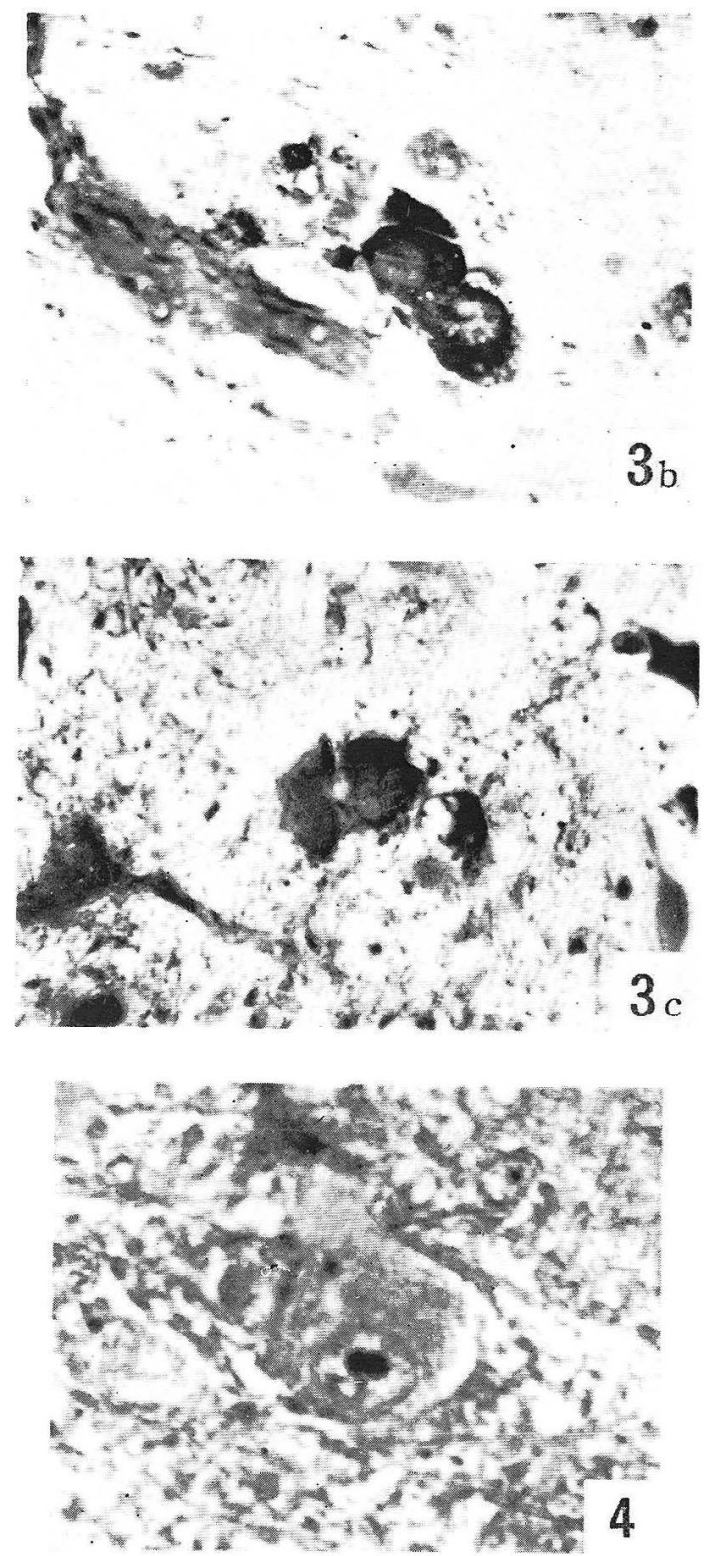